УДК 821.133.1.09-1

В.О. Паульс

\title{
ІДЕЯ КОХАННЯ КРІЗЬ ПРИЗМУ ЕСТЕТИКИ ПРИРОДИ В ВІРШІ «ПІСНЯ» СТЮАРТА МЕРРІЛЯ
}

Однією $з$ традицій поетів-символістів межі XIX-XX століть $\epsilon$ максимальне відсторонення від реального світу людини, тобто автори не допускали прямолінійності, чіткості та конкретики. Поети здебільшого робили природу основною художньою дійсністю, а чисельні природні явища стали об'єктами зображення [1, с. 377]. В роботах деяких французьких символістів, наприклад С. Мерріля та інших, можна відмітити гармонійне «вплетіння» естетики музики, що розглядаємо окремо від музичності, яка досягається завдяки римі. Музичне лексичне поле в жодному разі не домінує, але вбачаємо певне запозичення традиції в поетів-інструменталістів. Зауважимо, символісти не «тікали» від реальності, проте намагалися «підвести» читача до істини через зовнішні констатації. Таким чином, природа для символістів слугувала «посередником» між видимим символом (знаком) і його прихованою ідеєю (думкою). 3 точки зору поетівсимволістів, ідея без символу неможлива, та навпаки, бо символ не зароджується сам по собі, він утворюється на основі конкретної ідеї $[1$, c. 403]. При аналізі будь-якого символістського твору науковець займається дешифруванням, бо рухається від видимого фізичного до невидимого ментального, від символу до ідеї. Цей процес французький лінгвіст і філолог Гюстав Гійом (1883-1960) назвав методом психосистематики [2, с. 10]. Ця лінгво-філософська теорія мови на даний час ще недостатньої вивчена та представлена широкому колі літературознавців на терені України. Цією проблемою здебільшого займаються мовознавці 3 французької мови, але вважаємо, що урахування цього методу при аналізі символістських творів дозволить вийти за їх межі.

Актуальність статті полягає в інтерпретації твору одного 3 найменш досліджених франкофонних поетів-символістів Стюарта (C) В.О. Паульс, 2019

http://dx.doi.org/10.34142/2312-1076.2019.4.94.10 
134 Наукові записки ХНПУ ім. Г.С. Сковороди. Літературознавство, 2019, вип. 4(94)

Мерріля, ідіостиль якого будувався на світосприйнятті двох культур (французької та американської). Наукова проблема полягає в наявності прогалини - не зовсім повному розумінні дискурсу французького символізму. Інтерпретація поезії С. Мерріля сприяє осмисленню поетикального процесу, що дозволить заповнити лакуни, які наявні через помилкове ототожнення французького символізму виключно з такими поетами як Поль Верлен, Артюр Рембо, Стефан Малларме.

Метою статті $є$ розкриття ідеї Кохання крізь призму природної естетики в вірші «Пісня» С. Мерріля та виявленні індивідуальних авторських стилістичних фігур та тропів, що в подальшому дозволить чітко окреслити його ідіостиль.

У вірші «Пісня» (1887) французький поет Стюарт Мерріль (18631915) не замасковує об'єкт опису. Автор із першої строфи називає його, Кохання, що є нехарактерним для інших творів автора, таких як «Ноктюрн» (1887), «Балет» (1891), «Сподівання» (1909), тощо.

3 огляду на те, що перекладу вірша немає, ми пропонуємо власний переклад українською мовою. При роботі ми намагалися не втратити всі авторські символи, тому не ставили римування за мету; та максимально наближено до оригіналу передати мелодику твору через українські аналогічні номінації:

Chanson

A l'heure du réveil des sèves

L'Amour, d'un geste las, Sème les rimes et les rêves Parmi les lis et les lilas.

\section{Пісня}

У годину, коли все довкола силу набирає, один повільним жестом Кохання розсіває рими та мрії серед бузку та лілії.

La brise, soeur des hirondelles, Тим часом вітерець, ластівок братець,

Déferle son essor,

Et frôle de mille coups d'ailes Les corolles d'azur et d'or. все розбурхає, але оберігає блакитні й златаві вінчики від тисячі змахів крил, що за́ день ударяє.

Amour, pour fêter ta victoire

Les cieux se sont fleuris, Et mai t'auréole de gloire, $\mathrm{O}$ roi des Roses et des Ris! ([3])

Кохання, в ім'я твоєї перемоги, небо розквітає, а травень твою славу вінчає, О, короле Троянд і Посмішок! (тут і далі переклад мій-B. Паульс) 
Перше, на що звертаємо увагу, це композиція вірша. С. Мерріль виокремлює три строфи, кожна 3 яких є зображенням конкретного весіннього місяця, про що можливо здогадатися при аналізі наявних символів і динаміки; а також, відштовхуючись від третьої строфи, при зворотній реставрації природної послідовності місяців.

Щоб побачити та зрозуміти намір автора потрібно вірно пройти зворотній шлях від знаку до думки. Знак - це символ, фізична одиниця; тоді як думка - це ідея. Визначеннями «знак» і «ідея» користувавсяГ.Гійомпри роз'ясненнісвогометодупсихосистематики, а потім вже більше ніж століття до них запобігають послідовники його школи. За мету французький лінгвіст ставив ввести ментальний етап, що передує формуванню мови, яка, в свою чергу, реалізується в мовленні. Зробити це можливо виключно, якщо спиратися на мовленнєві елементи, бо якщо знак застосовано в мовленні, то вони (тобто елементи) мають фізичну природу [2, с. 10], вони існують. Г. Гійом вважав неправильним вивчати тільки знаки, так як це не дозволяє зрозуміти істину природу мови [2, с. 11]. Це наче сприймати символи за константи, не допускаючи їхню істину сутність. Взявши за основу його метод, аналізуємо авторську ідею, замасковану чисельними символами.

У першій строфі об'єктом опису є березень. Автор порівнює період пробудження природи та тї відродження навесні з тим, коли виникає відчуття симпатії; коли закоханні вірять у почуття та мріють про спільне щасливе майбутнє:

A l'heure du réveil des sèves (виокремлене словосполучення персоніфікація; вся строчка - метонімія).

У годину, коли все довкола силу набирає;

[...] parmi les lis et les lilas.

[...] серед бузку та лілії.

Щодо ритму строфи, то він повільний, неквапливий, про що робимо висновок через лексему «las» (втомлений):

L'Amour, d'un geste las,

Sème les rimes et les rêves (L'Amour [...] sème - персоніфікація).

Одним повільним жестом Кохання розсіває 
рими та мрії

серед бузку та лілії.

У другій строфі автор переходить до зображення квітня. Це другий етап розвитку стосунків: коли люди краще пізнають один одного; проявляються недоліки, але задля почуття намагаються зберегти найдорожче, не дають проблемами вбити любов:

La brise $[\ldots]$

[...] frôle de mille coups d'ailes

Les corolles d'azur et d'or (La brise [...] frôle - персоніфікація, corolles - метонімія).

Тим часом вітерець $[\ldots]$

але оберігає

блакитні й златаві вінчики

від тисячі змахів крил...

Метонімія «corolles» порівнює почуття 3 ботанічним терміном «вінчики», що символізує найдорожче, найламкіше.

Відчувається, що ритм строфи пожвавішав, прискорився через наступні слова та словосполучення: «brise» (легкий вітерець) «essor» (зліт, підйом), «mille coups d'ailes» (тисяча змахів крил).

У третій строфі автор вже не «натякає», а називає місяць - травень. Читач перестає здогадуватися про стан природи, все довкола квітне та живе: les cieux se sont fleuris (небо розквітає). Травень тріумфує навесні (о roi des Roses et des Ris! (о, король Троянд і Посмішок!)), а отже почуття перемогло і перетворилося в кохання (Amour, pour fêter ta victoire (кохання, в ім'я твоєї перемоги)).

Отже, друге, що обов'язково слід відмітити, це те, що всі три строфи є порівняннями. Хоча в вірші відсутні характерні ознаки цього тропу (а саме: сполучник «comme» (як); займенник «tel» (такий як, подібний до); прикметник «раreil» (такий самий як); конкретні дієслова чи дієслівні сполучення, що виражають порівняння між об' єктами), але завдяки декодуванню символів стає явним загальна картина твору.

Узагальнюючи, виводимо, що, по-перше, в вірші «Пісня» С. Меррілю вдалося перенести почуття любові в світ матеріальний 
та видимий. По-друге, завдяки дешифруванню символів, зуміли розібратися 3 первинною авторською ідеєю та розширити іiі межі, вийти за́ твір, чому сприяло переднє ознайомлення 3 Гійомським методом психосистематики. По-третє, виявивши всі засоби увиразнення мови, використані автором у вірші, констатуємо, що С. Мерріль віддав перевагу метафорам, персоніфікаціїта порівнянню, які допомагають йому досягти бажаного впливу на читача.

Подальший науковий пошук доречно спрямувати на втілення засад символізму в ліриці С. Мерріля, перетин чи протиставлення його ідіостилю з поетикою декадентства, що дозволить виокремити певне місце лірики поета в літературному дискурсі початку XX століття.

\section{Література}

1. Галич О. Теорія літератури: підручник. Київ: Либідь, 2008. 4-е видання. $488 \mathrm{c}$.

2. Реферовская Е.А. Философия лингвистики Гюстава Гийома: курс лекций по языкознанию. Москва: Издательство ЛКИ, 2007. Изд. 2-е. $128 \mathrm{c}$.

3. Merrill Stuart. Les gammes : vers. Paris : Chez Vanier Publ., 1887. 60 p. URL: https://archive.org/details/lesgammesvers00merruoft/page/n7 (дата звернення: 16.02.2020)

\section{References}

1. Galych O. Teoriya literatury [Theory of Literature]. Kyiv : Lybid Publ., 2008. 4th ed. 488 p. (In Ukrainian).

2. Referovskaya E.A. Filosofiya lingvistiki Gustava Giyoma : kurs lekcyi po yazykoznaniyu [Philosophy of the linguistics of Gustave Guillaume : course of lectures on Linguistics]. Moskva: LKL Publ., 2007. 2nd ed. 128 p. (In Russian).

3. Merrill Stuart. Les gammes : vers (1887). URL: https://archive.org/details/ lesgammesvers00merruoft/page/n7 (accessed 16 February 2020) 
138 Наукові записки ХНПУ ім. Г.С. Сковороди. Літературознавство, 2019, вип. 4(94)

\section{Анотація \\ В.О. Паульс. Ідея Кохання крізь призму естетики природи в вірші «Пісня» Стюарта Мерріля}

Франкофонний поет Стюарт Мерріль (1863-1915) є представником «молодого покоління» символістів. На ряду з Р. Гілєм, А. де Реньє, П. Кіяром i іншими він продовжив розвиток літературного напряму, підхопивши його на вершині популярності, й значуще збагатив його.

Вірш «Пісня» (1887) було написано в період пошуку поетом свого стилю, тому відмічаємо, що в творі авторська індивідуальність ще не домінує над основними символістськими канонами. Весна, пробудження природи після зими і її поденне відновлення - основна тема вірша. Робимо припущення, що автор бачив схожість природних змін із хвилюючими моментами у житті людини, коли легка симпатія перероджується в палке кохання. Проте, він не говорить про це відкрито, напряму, а «ховає» головну ідею під чисельними символами. Дешифрування «зриває» символістську оболонку та «оголює» ідею кожного символу окремо та ідею твору загалом. Свого часу зв'язок між знаком і наміром вивчав французький лінгвіст i філолог Гюстав Гійом. Він запровадив метод психосистематики, згідно якому науковець подумки проходить шлях назад від видимого фізичного до невидимого абстрактного.

Щодо музичності та звучанню, саме метафори створюють мелодійність тексту: на початку вірша темп нежвавий, але поступово він робиться більш ритмічним і динамічним.

Ключові слова: французький символізм, С. Мерріль, символ, ідея, метод психосистематики, природа, стилістичні фігури, тропи.

\section{Аннотация}

\section{В.А. Паульс. Идея Любви через призму эстетики природы в стихотворении «Песня» Стюарта Мерриля}

Франкоязычный поэт Стюарт Мерриль (1863-1915) является представителем «молодого поколения» символистов. К ряду с Р. Гилем, А. де Ренье, П. Кьяром и другими, подхватив литературное направление на вершине его популярности, он продлил его существование и значительно обогатил его своими работами.

Стихотворение «Песня» (1887) было написано в период поиска поэтом своего стиля, поэтому следует отметить, что в произведении авторская индивидуальность еще не доминирует над основными символистскими 
канонами. Весна, пробуждение природы после зими и ее восстановление день за днем - вот основная тема стихотворения. Предполагаем, что автор заметил сходство природных изменений и волнительных моментов в жизни человека, когда легкая симпатия перерождается в страстную любовь. Свою догадку он не высказывает в открытую, а скрывает главную идею под многочисленными символами. Дешифровка «срывает» символистскую оболочку и «оголяет» идею каждого символа по отдельности, так же как и общую идею произведения. В свое время связь между знаком и намерением изучал французский лингвист и филолог Гюстав Гийом. Он ввел метод психосистематики, согласно которому исследователь мысленно проходит путь назад от видимого физического до невидимого абстрактного.

Что касается музыкальности и звучанию, именно метафоры создают мелодичность текста: сначала, темп неторопливый, но постепенно он становится ритмичнее и динамичнее.

Ключевые слова: французский символизм, С. Мерриль, символ, идея, метод психосистематики, природа, стилистические фигуры, тропы.

\section{Summary}

\section{Pauls. Idea of Love through the prism of the esthetics of nature in the poem "Song" by Stuart Merrill}

Francophone poet Stuart Merrill (1863-1915) is a representative of the "young generation" of symbolists. Alongside R. Ghil, H. de Regnier, P. Quillard and others the poet continued developing the poetic movement having picked it up on the top of its fame and therefore significantly enriched it.

The poem "Song" (1887) was written at the period of seeking the personal style and poet's self-identification, so it is noticed that in the poem the author's identity still does not dominate basic symbolistic canons. Spring, awakening of the nature after winter and its daily restoration form the main theme of the poem. Although, it is supposed that the author saw the resemblance between natural changes and thrilling moments in somebody's life when light sympathy develops into passionate love. However, S. Merrill did not express it directly, but he "hid" the point behind numerous symbols. Deciphering "tears off" the symbolistic cover and "bares" the idea of each separate symbol as well as the main idea of the work. Those days the link between a sign and an intention was studied by French linguist and philologist Gustave Guillaume. He introduced the method of psychosystematic according to which a scientist mentally tracks back the way from visible and physical to invisible and abstract. 
140 Наукові записки ХНПУ ім. Г.С. Сковороди. Літературознавство, 2019, вип. 4(94)

As for musicality and sounding, namely metaphors make the melody of the text, at the beginning of the poem the tempo is unhurried, but it is gradually becoming more rhythmic and dynamic.

Key words: French symbolism, Stuart Merrill, symbol, idea, method of psychosystematic, nature, stylistic devices, tropes.

\section{Інформація про автора}

Паульс Вікторія Олександрівна - аспірантка кафедри світової літератури Харківського національного педагогічного університету імені Г.С. Сковороди; вул. Валентинівська, 2, м. Харків, 61168, Україна; e-mail: viktoriya479pauls@gmail.com; https://orcid.org/0000-0002-9569-1208 